\title{
GROTESKOWE PRZEKSZTAKCENIA KONWENCJI HORRORU W FILMIE MROCZNE CIENIE TIMA BURTONA
}

https://doi.org/10.25312/2451-2737.14/2019_05ts

Streszczenie

Groteska jest jedną z najstarszych kategorii estetycznych, a jej rozmaite realizacje można odnaleźć w sztuce z różnych okresów. Jest ona również obecna w różnych dziedzinach współczesnej sztuki, w tym sztuce filmowej. Groteska pojawia się zarówno w niezależnych dziełach awangardowych, jak i w wysokobudżetowych produkcjach hollywoodzkich. Jednym z autorów stosujących groteskę jako środek artystycznej ekspresji jest amerykański reżyser Tim Burton. Jego rozpoznawalny styl charakteryzuje się między innymi gatunkową subwersją polegającą na przekształcaniu istniejących konwencji gatunkowych i nadawaniu im nowego kontekstu oraz znaczenia. Burton wykorzystuje tę strategię najczęściej wobec horroru, który w jego filmowych wizjach łączy w sobie elementy grozy i komizmu. W artykule przedstawiono przykłady groteskowych przekształceń konwencji horroru w filmie Mroczne cienie. Filmową analizę poprzedza próba zdefiniowania pojęcia groteski.

Słowa kluczowe: groteska, horror, groza, komizm, Tim Burton, Mroczne cienie

\section{Grotesque transformations of horror genre conventions in Tim Burton's Dark Shadows Summary}

Grotesque is one of the oldest aesthetic categories, and its various works can be found in different periods of art. It is also present in various fields of contemporary art, including film art. Grotesque appears in both independent avant-garde works and high-budget Hollywood productions. One of the film directors using grotesque as a form of artistic expression is the American Tim Burton. His recognisable style characterised by, among others, a subversion of genres through transforming existing genre conventions and giving them a new context and 
a new meaning. Burton applies this strategy most often to horror, which, in his films, combines elements of horror and comedy. This article presents examples of grotesque transformations of horror genre conventions in the movie Dark Shadows. The film analysis is preceded with an attempt to define the theoretical concept of grotesque.

Keywords: grotesque, horror, terror, humour, Tim Burton, Dark Shadows

Tim Burton należy do najbardziej oryginalnych twórców we współczesnym kinie. Pomimo współpracy z największymi wytwórniami Hollywood, jego filmy wykraczają poza trendy funkcjonujące w kinie popularnym, zarówno na poziomie treści, jak i formy. Jak zauważa Joanna Zabłocka-Skorek, twórczość Burtona można określić mianem kina autorskiego, któremu bliżej jest do artystycznych produkcji europejskich niż do amerykańskich blockbusterów (Zabłocka-Skorek, 2010: 331). Poza bogatą i drobiazgową kreacją świata przedstawionego, wyrazistymi i ekscentrycznymi bohaterami oraz powracającymi motywami i tematami burtonowski styl odznacza się gatunkową subwersją. Polega ona na wykorzystaniu rozpoznawalnych cech gatunkowych, którym twórca nadaje nowy wymiar semantyczny (Zabłocka-Skorek, 2010: 331-356; Żakieta, 2013: 267). Strategia ta umożliwia Burtonowi grę z konwencjami i gatunkami filmowymi, schematami przedstawiania oraz oczekiwaniami odbiorczymi widza. Pozwala to również zapobiec twórczej sztampie, nadaje dziełom oryginalności, a przed wnikliwym odbiorcą otwiera szerokie możliwości interpretacyjne. Przedmiotem inspiracji Burtona jest między innymi horror filmowy, którego wzorce i schematy gatunkowe reżyser poddaje autorskim przekształceniom. Przyjmują one często groteskową formę, dzięki której filmowa rzeczywistość zyskuje karykaturalny rys, jest ukazana w krzywym zwierciadle i poddana hiperbolizacji. Burtonowskie ingerencje w poetykę horroru mają zwykle humorystyczny, parodystyczny lub ironiczny wydźwięk. Są one dostrzegalne w filmach, takich jak: Frankenweenie (1984, 2012), Sok z Żuka (1988), Batman (1989), Edward Nożycoręki (1990), Jeździec bez Głowy (1999), Gnijaca Panna Mtoda (2005), Sweeney Todd (2007), Mroczne cienie (2012) oraz Osobliwy dom Pani Peregrine (2016). Celem niniejszej pracy jest ukazanie przykładów groteskowych przekształceń konwencji horroru w filmie Mroczne cienie. Przed przystąpieniem do analizy dzieła Burtona warto jednak prawidłowo zdefiniować pojęcie groteski jako punkt wyjścia do dalszych rozważań.

Pomimo długiej tradycji w sztukach wizualnych, muzyce i literaturze oraz bogatego zbioru opracowań teoretycznych ukazujących się od końca XVIII wieku groteska nie doczekała się jednolitej definicji, która nie budziłaby wątpliwości badaczy i jednoznacznie określała zakres problemowy zjawiska. Groteska jest bowiem labilną i trudną do uchwycenia kategorią estetyczną, która ewoluowała i zmieniała swoje oblicza na przestrzeni wieków, zyskując przy tym rozmaite znaczenia, funkcje i konotacje, zależnie od sytuacji historyczno-światopoglądowej oraz dominujących w danym czasie tradycji artystycznych (Buryła, 2006: 128-130; Głowiński, 2003: 8-10; Sokół, 1970: 330). Warto zastanowić się nad istotą tego zjawiska oraz jego cechami 
dystynktywnymi. Niemniej, kompleksowy przegląd naukowych definicji groteski, począwszy od końca XVIII stulecia, jest tematem na osobną rozprawę, toteż na potrzeby niniejszej pracy dokonam skróconej charakterystyki groteski, skupiając się na wybranych, współczesnych sposobach definiowania tego terminu ${ }^{1}$.

Nowoczesne badania nad groteską otwierają rozważania Wolfganga Kaysera, dla którego groteskowość może uwidaczniać się na trzech poziomach: w procesie twórczym, dziele oraz jego odbiorze (Kayser, 2003: 18). Mianem groteskowych badacz określa twory obce człowiekowi, których natura nie jest powszechnie znana. Groteskowe będzie zatem to, co tajemnicze, dziwaczne, szokujące, niepojęte, niespójne i absurdalne, budzące niepokój oraz przerażenie, a także funkcjonujące wbrew prawom logiki, sensu i rozumu (Jennings, 2003: 282-305; Stańczuk, 2015: 83; Stolarek, 2014: 156). Groteskowy charakter mają ponadto osobliwe połączenia materii ożywionej z nieożywioną, a także zachodząca przy tym dysproporcja. Do popularnych motywów groteskowych Kayser zalicza między innymi: „żywe istoty przekształcone w manekiny, automaty, marionetki i twarze zastygłe w maski [...], wyszczerzone czaszki i poruszające się szkielety" (Kayser, 2003: 23). Znamiona groteski ma również kontakt z osobą dotkniętą szaleństwem i obłędem, które Kayser charakteryzuje jako obcy, nieludzki pierwiastek dręczący duszę chorego (Kayser, 2003: 23). Badacz postrzega groteskowość jako „świat, który stał się obcy”, czym zdaje się sugerować, że termin ten odnosi się nie tylko do konkretnych obiektów i ich właściwości, ale również do pewnej struktury świata i jego percepcji (Kayser, 2003: 24-25). Jak zauważa Kayser, obecność groteskowych tworów ujawnia pozorność naszej orientacji w świecie i wywołuje poczucie destabilizacji. Obcowanie z nimi wywołuje na przemian przerażenie oraz śmiech. Jest to jednak śmiech gorzki, szyderczy, cyniczny i niejako sataniczny (Kayser, 2003: 27). Pojawia się samoistnie, w obliczu bezradności i braku innej metody na rozładowanie napięcia. Śmiech może mieć jednak wymiar pozytywny i terapeutyczny, stając się sposobem na ujarzmienie grozy, przezwyciężenie lęku oraz zagubienia. Potwierdzają to słowa Kaysera, który twierdzi, że „ukształtowanie czegoś groteskowego jest próbą zaklęcia i okiełznania wszystkiego, co w świecie demoniczne" (Kayser, 2003: 24-25).

Podobną do Kaysera koncepcję groteski prezentuje Lee Byron Jennings. Zdaniem Jenningsa, dany twór jest tym bardziej groteskowy, im bardziej przypomina wyglądem człowieka, choć owo podobieństwo może być tworem wyobraźni odbiorcy i wynikać z jego subiektywnej oceny. „Twór groteskowy to postać wyobrażona w kategoriach kształtu ludzkiego, lecz pozbawiona rzeczywistego człowieczeństwa" pisze Jennings (2003: 43-44). Istotą groteski jest ukazanie zniekształcenia zaistniałego na skutek połączenia elementów przerażających i śmiesznych. Jennings wyjaśnia tę właściwość następująco:

\footnotetext{
1 Przyjęło się uważać, że współczesna forma groteski wykształciła się w wieku XX, toteż w pierwszej kolejności przywołam poglądy badaczy z tego okresu, by następnie przejść do omówienia definicji groteski sformułowanych w wieku XXI.
} 
Groteska prezentuje w niewinnej masce to, co okropne, a jej żartobliwość jest stale na skraju załamania się pod naciskiem ukrytej grozy. Oba aspekty muszą być w równym stopniu dostrzegalne w danym obiekcie, przynajmniej wtedy, gdy nie zachodzą takie okoliczności, które sprzyjałyby zbytniemu akcentowaniu jednej lub drugiej fazy (Jennings, 2003: 55).

Groteskowość ujawnia się przede wszystkim podczas odbioru dzieła, budząc u odbiorcy jednocześnie lęk i rozbawienie (Jennings, 2003: 46). Podobnie jak Kayser Jennings dostrzega w grotesce sposób na przezwyciężanie lęku i niepokoju za pomocą humoru. Rozbrajanie demoniczności poprzez humor to zdaniem badacza instynktowny, podświadomy mechanizm zapewniający utrzymanie równowagi psychicznej: „Element okropności i związane z nim zagrożenie muszą być zamaskowane poprzez pozory czegoś małego, pozbawionego znaczenia, zasługującego na wzgardę i śmiesznego. Groteska to demoniczność przemieniona w trywialność" (Jennings, 2003: 57). Nie mniej istotne są według Jenningsa groteskowe sytuacje, które budzą ambiwalentne emocje u odbiorcy i naruszają jego wyobrażenia o świecie, wywołując wrażenie groteskowości. Jak pisze badacz:

Można sobie wyobrazić pewien typ sytuacji, który cechuje daleko posunięte zniekształcenie o aspekcie równie przerażającym, jak i śmiesznym, i gdzie niepodzielnie panuje absurd. Zniekształcenie polega tu nie na odejściu od kształtu ludzkiego, lecz na pogwałceniu norm doświadczenia naszego codziennego życia (Jennings, 2003: 58).

Do groteskowych tworów Jennings zalicza między innymi gotyckie chimery i maszkary, renesansowe wyobrażenia postaci ludzkich przechodzących w formy roślinne, zwierzęce oraz przedmioty nieożywione, a także demonicznych klaunów i błaznów, osoby szpetne i z deformacjami ciała, jak również ludzkie szkielety i czaszki - podobne do marionetek i stwarzające pozory uśmiechu. Wiele z wyżej wymienionych form groteskowych, o których piszą Kayser oraz Jennings, występuje w filmowych światach przedstawionych Tima Burtona, które łączą w sobie elementy fantastyki, horroru i komedii, a ekranowa groza przeplata się w nich z komizmem (Weishaar, 2012: 55).

Kolejne właściwości groteski wyłaniają się z rozważań Władimira J. Proppa, który definiuje ją jako skrajną i szczytową formę przesady. Zdaniem Proppa, stosowanie groteski powoduje wrażenie odrealnienia prowadzące do postrzegania jej w kategoriach szeroko rozumianej fantastyki². Jak zauważa badacz, „w grotesce przesada osiąga takie rozmiary, że staje się czymś wręcz monstrualnym. Wychodzi ona całkowicie poza granice realności i wkracza w dziedzinę fantazji" (Propp, 1977: 48 za Janus-Sitarz, 1997: 19). Groteska rządzi się własnymi prawami, nie podlega wymogom prawdopodobieństwa, związkom przyczynowo-skutkowym ani konsekwencjom psychologicznym (Janus-Sitarz, 1997: 60). Daje to korzystającym z niej artystom dużą swobodę podczas kreowania światów przedstawionych, w których mają prawo zaistnieć abstrakcyjne i wynaturzone byty, relacje oraz sytuacje. Powino-

\footnotetext{
2 Iwona Kolasińska klasyfikuje literaturę grozy i kontynuujący jej tradycję horror filmowy jako twórczość fantastyczną, co uzasadnia obecność elementów groteskowych w dziełach przynależnych temu gatunkowi (horrorowi) lub nawiązujących do jego założeń estetyczno-formalnych (zob. Kolasińska, 1998: 115-131).
} 
wactwa groteski ze światem fantazji dostrzega również Maciej Gutowski definiujący groteskę jako „rodzaj przedstawień, w których zostały wykreowane twory fantastyczne, irracjonalne, powstałe przeważnie w wyniku swobodnego połączenia różnorodnych, nie przystających do siebie elementów" (Janus-Sitarz, 1997: 20). Podobny sąd formułuje Marta Piwińska, definiując groteskę jako „osobną rzeczywistość, samodzielną strukturę, w której elementy znane łączą się w zdeformowane całości - hybrydy - złożone z obcych sobie elementów; w której połączenia kontrastowe [...] wywołują sprzeczne wrażenia i reakcje" (Piwińska, 1967: 14 za Janus-Sitarz, 1997: 40). Powyższe ujęcia groteski wskazują na jej potencjał światotwórczy. Zestawianie ze sobą przeciwstawnych wartości prowadzi do wytworzenia się całkiem nowych znaczeń. Pod wpływem łączenia elementy groteskowe ulegają deformacji, co sprawia, że wydają się pokraczne, wynaturzone, odrażające lub szpetne z punktu widzenia „klasycznej” estetyki (Janus-Sitarz, 1997: 32-34). Ich monstrualność i wrażenie obcości może wywoływać sprzeczne reakcje emocjonalne, takie jak śmiech czy przerażenie, zależnie od okoliczności oraz subiektywnej oceny odbiorcy. Można więc stwierdzić, że groteskowe twory powstają w wyniku reinterpretacji (deformacji) uprzednio istniejących form, które w swojej nowej, hybrydycznej postaci zyskują nowy kontekst, właściwości oraz odmienne od dotychczasowego znaczenie. Stają się zatem nośnikiem nowych idei i wprowadzają nową jakość W zastane struktury znaczeniowe. Badacze groteski zwracają uwagę na jej wymiar krytyczny oraz tendencję do komentowania rzeczywistości pozatekstowej. Dla Jeana Onimusa groteska jest stanem świadomości towarzyszącym refleksji nad życiem. Pojawia się wskutek „porównywania rzeczy, jakimi są w głębi, z takimi, jakimi wydają się nam na powierzchni" (Onimus, 2003: 74). Podstawowym celem groteski jest według Onimusa demaskowanie codziennej rzeczywistości poprzez odkrywanie i uwidacznianie jej ukrytych cech, na które nie zwracamy, bądź nie chcemy zwracać, uwagi. Groteska pokazuje świat „pod powiększeniem”, w sposób wyraźny i dosadny, okrutnie obiektywny, wykluczający idealizowanie i „ubarwianie" rzeczywistości. Ponieważ groteski nie obowiązują żadne normy społeczne, etyczne czy estetyczne, pokazuje ona świat takim, jakim jest naprawdę. Świadomość istnienia innej rzeczywistości od tej powszechnie znanej może szokować i fascynować, a jednocześnie dezorientować oraz budzić lęk i niepokój. W obliczu kryzysu światopoglądowego u odbiorcy może pojawi się również śmiech. Jest to jednak śmiech szczególny - desperacki i wyzwalający - powodowany koniecznością rozładowania napięcia i emocjonalnego zdystansowania. Jego natura jest bardzo ulotna, gdyż pod wpływem refleksji może szybko zamienić się w lęk i trwogę spowodowaną zderzeniem z okrutną prawdą o świecie oraz degradacją powszechnych ideałów i wartości. Prowokacyjność groteski wobec zastanych norm i konwencji społecznych oraz kulturowych jest również przedmiotem rozważań Anny Janus-Sitarz. Jako podstawową właściwość groteski badaczka wskazuje demistyfikację wartości, które w powszechnym przekonaniu mają status fundamentalnych i niepodważalnych: „groteska wymierzona jest przeciwko mitom, absolutom, stereotypom. Podważanie prawd uznawanych za jedynie słuszne, kpina z tak zwanych oczywistości, szarganie "świętości»" - to zdaniem Janus-Sitarz jedna z cech 
dystynktywnych groteski (1997: 73). Podobny sąd wygłasza Michał Głowiński, który następująco charakteryzuje deziluzyjną funkcję groteski:

Pierwszą i najistotniejszą właściwością groteski jest to, że wchodzi ona w konflikt z przyjętymi wyobrażeniami utrwalonymi w świadomości społecznej (lub z wyobrażeniami jej narzucanymi), że neguje utarte przekonania na temat struktury świata, zachowań ludzkich, historii, życia społecznego, psychologii i że - następnie - kwestionuje oficjalne systemy aksjologiczne (Głowiński, 2000: 155).

Jak zauważa Głowiński, groteska w swych najwybitniejszych przejawach funkcjonuje jako narzędzie opisywania i diagnozowania świata. Pokazuje sprzeczności określające współczesną rzeczywistość, ujawnia drugą stronę zjawisk, sprzeciwia się powszechnie obowiązującym porządkom i wyobrażeniom społecznym, należącym do kultury oficjalnej, a więc niepoddawanym kontroli i przyjmowanym bezkrytycznie (Głowiński, 2003: 10-13). Badacz zwraca ponadto uwage na intertekstualny wymiar groteski. Utwory groteskowe odnoszą się krytycznie do innych tekstów kultury, "będących przekazem ustabilizowanego, oficjalnego ujmowania świata"3. Krytyka ta może przyjmować postać karykatury, parodii, satyry lub ironii. Znamiennym dla groteski zabiegiem jest odseparowanie elementu utrwalonego w świadomości społecznej od jego pierwotnego kontekstu: „przyjęty element traci swoje tradycyjne znaczenie, staje się problematyczny, ukazuje się w nowym świetle" - pisze Głowiński (2000: 155-156). Konsekwencją tego jest powstanie nowego obiektu rządzącego się własnymi zasadami i mającego polemiczny charakter wobec dotychczasowych reguł, na których opierało się funkcjonowanie pierwowzoru (Głowiński, 2000: 155-156). Z powyższych rozważań wyłania się zespół właściwości, którymi charakteryzuje się groteska. Powstaje ona w wyniku połączenia ze sobą występujących jednocześnie pierwiastków przeciwstawnych - stanów, emocji, wartości, rzeczy wbrew odmiennej naturze łączonych zjawisk (Stańczuk, 2015: 82). Zestawianie na jednej płaszczyźnie przeciwieństw powoduje ich zniekształcenie i pozbawia je pierwotnego kontekstu. Pozwala również wydobyć z nich nowy, zaskakujący sens oraz znaczenie, a także wykreować całkiem nową, autonomiczną wizję rzeczywistości, której nie obowiązują zasady prawdopodobieństwa, związki przyczynowo-skutkowe i czasowo-przestrzenne oraz prawa logiki. Popularną odmianą groteski jest połączenie elementów komicznych z elementami grozy. Może to wywoływać u odbiorcy sprzeczne reakcje emocjonalne oscylujące pomiędzy śmiechem i przerażeniem. Rola śmiechu odgrywa tu szczególną rolę, ponieważ pozwala przezwyciężyć lęk i niepokój wywołany elementami grozy. W nieco szerszym ujęciu groteska staje się metodą na ujarzmienie grozy i rozbrajanie demoniczności świata poprzez humor, jak słusznie zauważyli Kayser i Jennings. Groteska umożliwia polemizowanie z rzeczywistością pozatekstową i jej elementami przez intertekstualne odniesienia, ukazywanie różnorodnych zjawisk w odmiennym świetle, ujawnianie rozmaitych sprzeczności i kontrowersji oraz podważanie istniejących porządków świata.

\footnotetext{
3 Intertekstualność zakłada istnienie zamierzonych przez autora relacji - wpływów, zależności, zapożyczeń i związków - łączących jeden tekst kultury z drugim (zob. Głowiński, 1986: 87-98; 2003: 155-156).
} 
Podobną strategię przyjmuje Tim Burton, który w swojej niebanalnej twórczości często inspiruje się poetyką filmów grozy, lecz interpretuje ją na swój sposób i poddaje autorskim przekształceniom. Reżyser redefiniuje klasyczne wzorce przedstawiania oraz rozpoznawalne cechy gatunkowe horroru, nadając im nowy kontekst i znaczenie. Zgodnie z teorią Noëla Carrolla, autora klasycznej już książki Filozofia horroru..., podstawowym wyróżnikiem tego gatunku jest uczucie grozy, którą wywołuje u widzów obecność potwora w świecie przedstawionym, jak również myśl o tym, że mógłby on naprawdę istnieć (Carroll, 2004: 38-54). Należy przy tym zakładać, że reakcje emocjonalne widzów - niepokój, przerażenie, wstręt, odraza, obrzydzenie - są tożsame z reakcjami bohaterów na prześladującego ich potwora, który zagraża im pod względem fizycznym lub psychicznym (Carroll, 2004: 39-63). Silne emocje budzi zarówno obecność potwora, jak i samo oczekiwanie na jego pojawianie się. Monstrów nie można jednak uznać za kryterium konieczne horroru, ponieważ występują one także w baśniach i mitach. Prowadzi to do wniosku, że głównym wyznacznikiem horroru jest reakcja widzów w postaci lęku i przerażenia. Poza potworami mogą je powodować wszelkie anomalie zaburzające naturalny porządek, jak również sugestywna scenografia, niepokojąca muzyka, odgłosy i dźwięki oraz właściwie dobrane chwyty dramaturgii filmowej, na przykład odpowiedni montaż, praca kamery czy oświetlenie (np. umiejętna gra światłocieniem). Chociaż większość dzieł Burtona bazuje na klasycznym modelu horroru, straszenie widzów nie jest ich głównym celem.

Burton dekonstruuje klasyczne konwencje gatunkowe horroru ${ }^{4}$, poddaje je polemice i rozmaitym przekształceniom, by wykreować z nich niebanalną rzeczywistość z pogranicza marzeń sennych i jawy, fantastyki i realności, w której dominantę estetyczną stanowi groteska. Reżyser przeplata ekranową grozę z humorem, a tragizm bohaterów równoważy komizmem. Łącząc ze sobą sprzeczne wartości, tworzy zabawne paradoksy i dysonanse, które wywołują wrażenie odrealnienia, pozwalają zdystansować się emocjonalnie widzom i przezwyciężyć uczucie strachu śmiechem. Dodatkowo Burton wprowadza do swoich filmów błyskotliwe żarty, komiczne gagi i sytuacje, nie stroniąc od ironii, absurdu i czarnego humoru. Przywodzi to na myśl obserwacje Wolfganga Kaysera i Lee Byrona Jenningsa, dla których groteska służy rozbrajaniu demoniczności świata poprzez humor i zwalczaniu towarzyszącej jej grozy śmiechem. Strategię twórczą Tima Burtona najlepiej zobrazować przykładami, toteż dalszą część pracy poświęcam analizie filmu Mroczne cienie (2012) ukierunkowanej na groteskowe przekształcenia konwencji horroru.

Burtonowskie inspiracje horrorem obejmują między innymi przestrzeń, w której rozgrywa się akcja filmu. Rodzinna posiadłość Collinsów przypomina wyglądem ponure zamczyska z gotyckich powieści grozy, będące siedliskiem zła i mrocznych tajemnic. Przybywającej do Collinwood Victorii ukazuje się niepokojący pejzaż -

\footnotetext{
4 Źródłem inspiracji dla Burtona jest między innymi estetyka niemieckiego ekspresjonizmu, klasyczne kino grozy (w szczególności filmy Rogera Cormana), pisarstwo Edgara Alana Poe, a także powieść gotycka, której pierwowzorem jest książka Zamczysko w Otranto (1764) Horace'a Walpole'a.
} 
otoczony dziką przyrodą stary dwór na wzgórzu. Prowadzi do niego ścieżka idąca środkiem gęsto porośniętego lasu. Stojąca przed bramą Victoria zdaje się wahać przed jej przekroczeniem, jakby wyczuwała złowrogą aurę Collinwood i czające się tam niebezpieczeństwo. Zastosowane w kolejnych ujęciach szerokie kadrowanie kreuje atmosferę grozy i osaczenia, ukazując w oddali sylwetkę Victorii idącej pośród wysokich, starych drzew, a następnie przez wielki, zaniedbany dziedziniec. Prezentowany na kolejnych ujęciach gotycki dom Collinsów jest kadrowany tak, by przytłaczać swoimi rozmiarami i uczynić widniejącą w tle Victorię jeszcze mniejszą wizualnie i - w domyśle - bardziej zagubioną. Nawet w świetle dziennym widok ciemnych, porośniętych bluszczem murów, ostro zakończonych wieżyczek i strzelistych łuków oraz poszarzałych okien może budzić trwogę. Równie ponura aura panuje wewnątrz zabytkowej rezydencji Collinsów. Olbrzymie, bogato zdobione wnętrza pokryte są warstwą kurzu i pajęczą siecią - rekwizytami typowymi dla opowieści grozy. Misternie rzeźbione kolumny i ozdoby przedstawiają morskie stworzenia, bóstwa i nimfy, które wyglądają jak żywe istoty zaklęte w kamień za sprawą magii (w finale ożywają i zwracają się przeciwko bohaterom). Collinwood kojarzy się z transylwańskim dworem hrabiego Draculi z filmu (1992) Francisa Forda Coppoli bądź wcześniejszych ekranizacji powieści Brama Stokera ${ }^{5}$. Łączy je motyw starego, zniszczonego domu, w którym czają się różne okropieństwa i nadprzyrodzone moce. Iwona Kolasińska określa ten typ przestrzeni jako „estetykę potworności i grozy, [...] nastrojotwórczą scenerię krajobrazową akcentującą izolację i osaczenie" (Kolasińska, 1998: 114-115). Podobne spostrzeżenia ma Anita Has-Tokarz, której zdaniem popularnym miejscem akcji w filmach grozy są przestrzenie domów. Jak pisze:

Jednym z bardziej wyrazistych obszarów będących tłem dla niesamowitych zdarzeń i działań postaci jest w horrorze przestrzeń domu. [...] Nie jest to przestrzeń przyjazna bohaterowi, ale złowroga, posępna, zagrażająca [...]. Dom przytłacza bohatera horroru, stara się go ujarzmić, zniewolić i pognębić. [...] Na ogół mamy tu do czynienia z posiadłościami w stadium totalnego upadku, degrengolady, zepsucia, zamierania, powolnego rozkładu i gnicia (Has-Tokarz, 2011: 193-195).

Collinwood wydaje się idealnym miejscem akcji dla filmów grozy. Pojawia się w nim jednak kilka szczegółów, które odstają stylistycznie od reszty i burzą konwencję strasznego dworu. Przykładem rozładowania atmosfery grozy poprzez wizualną groteskę jest pokój nastoletniej Carolyn. Jego aranżacja nawiązuje do stereotypowych wyobrażeń na temat pokojów amerykańskiej młodzieży. Pomieszczenie pełne jest plakatów z podobiznami gwiazd rocka, odręcznych notatek i rysunków, kiczowatych ozdób, dziwacznych gadżetów i niedbale porozrzucanych ubrań. Panujący tam wizualny chaos i stylistyczny eklektyzm odzwierciedla buntowniczą naturę dorastającej dziewczyny. Dominują tam kontrastowe połączenia kolorów. Najbardziej rzuca się w oczy pierzasty, jaskrawożółty dywan na tle ciemnofioletowej ściany. W przeciwieństwie

\footnotetext{
5 Podobną scenerię można spotkać w wielu filmach inspirowanych gotyckim horrorem. Skojarzenia z dworem hrabiego Draculi są jednak nieuniknione nie tylko ze względu na podobieństwo tematyczne filmów Coppoli i Burtona, ale również z uwagi na fakt, że bohater powieści Brama Stokera jest jednym z najsłynniejszych czarnych charakterów w kulturze popularnej.
} 
do innych pomieszczeń pokój Carolyn jest dość dobrze oświetlony, co razem z jego osobliwym wystrojem całkowicie burzy atmosferę grozy. Jego groteskowość jest bardziej wyrazista w zestawieniu ze stonowanymi kolorystycznie, gotyckimi wnętrzami rezydencji Collinsów, które prezentują się przy nim niepozornie i mało ekstrawagancko. Podobny zabieg wizualny został zastosowany przy aranżacji sekretnego pomieszczenia z robótkami ręcznymi Elizabeth. Schowek wypełniony jest kolorowymi, tandetnymi ozdobami z włóczki i równomiernie oświetlony. Wrażenie groteskowości wywołuje jego bliskie sąsiedztwo ze stylizowanym na gotyk pokojem Elizabeth. Można przypuszczać, że kobieta ma słabość do kolorów i kiczowatych ozdób, którą na co dzień ukrywa pod pozorami elegancji przejawiającej się zarówno w wystroju wnętrz, jak i gustownych, stonowanych kolorystycznie strojach. Patrząc przez pryzmat ponurej aury Collinwood, przypadkowe odkrycie sekretnego schowka Elizabeth wywołuje zaskoczenie i śmiech widzów. Zarówno w przypadku pokoju Carolyn, jak i kolorowej skrytki Elizabeth ich groteskowość ujawnia się wskutek zestawienia ze sobą przestrzeni o odmiennym charakterze wizualnym. Przejawem groteskowych deformacji są również sekwencje, w których atmosfera grozy przeplata się z komizmem. Obrazuje to scena, w której robotnicy drogowi trafiają przypadkiem na zakopaną pod ziemią żelazną trumnę z uwięzionym w niej rozwścieczonym wampirem Barnabasem Collinsem $^{6}$. Nieświadomi zbliżającego się zagrożenia przecinają łańcuchy zabezpieczające wieko trumny i wyzwalają z niej wampira po ponad dwóch wiekach niewoli. Po wydostaniu się ze skrzyni Barnabas dokonuje widowiskowej masakry na ludziach, prezentując swoje diaboliczne oblicze. Następnie wysysa krew z jednego z robotników, zaspokajając tłumione przez wieki pragnienie. Wydarzenia te mają bezsprzecznie negatywny wydźwięk i są źródłem ekranowej grozy. Dramatyzmu całej scenie dodaje niepokojąca muzyka instrumentalna, która wybrzmiewa w tle. Nie trzeba jednak długo czekać, by groza wywołana śmiercią robotników została rozbrojona poprzez serię komediowych gagów, a cała sytuacja nabrała cech groteski. Nasycony krwią wampir rozgląda się po okolicy i natrafia wzrokiem na logo sieci restauracji McDonald's. Myli charakterystyczny kształt litery „M” z symbolem Mefistofelesa, który zapamiętał z okultystycznych ksiąg. Barnabas wydaje się zatrwożony swoim odkryciem, tymczasem dla współczesnego widza jest to okazja do śmiechu. Nieco później Barnabas oślepiony światłami nadjeżdżającego samochodu szykuje się na sądny dzień i spotkanie $z$ diabłem. Wychowany w epoce znanej z mitów, legend i ludowych wierzeń, utożsamia światła pędzącej maszyny z czarcimi ślepiami ${ }^{7}$. Ciąg zabawnych zdarzeń kontynuuje piesza wędrówka wampira do rodzinnej posiadłości prowadząca przez centrum miasta. Ku zaskoczeniu Barnabasa Collinsport zmieniło się nie do poznania.

\footnotetext{
${ }^{6}$ Motyw uwięzienia wampira $\mathrm{w}$ trumnie i zakopania go żywcem pod ziemią jest nawiązaniem do filmu Wywiad z Wampirem Neila Jordana, w którym tej samej karze został poddany jeden z bohaterów, wampir Louis de Pointe du Lac.

7 Paradoksalnie Barnabas jako człowiek przemieniony w wampira potwierdza sobą prawdziwość legend o nocnych krwiopijcach. Być może dlatego traktuje spotkanie z diabłem jako prawdopodobny scenariusz. W filmie Burtona urzeczywistniają się również legendy o duchach (Josette DuPres), wiedźmach (Angelique Bouchard) i wilkołakach (Carolyn Stoddard), a magia i nadprzyrodzone zjawiska wpisują się w logikę świata przedstawionego.
} 
Zaintrygowany wampir przygląda się kolorowym szyldom i wystawom sklepowym, lokalom rozrywkowym i osiągnięciom techniki, o których nikt nie słyszał przed dwustoma laty. Efekt groteskowości potęguje kontrapunkt muzyczny w postaci lekkiej i przyjemnej muzyki rozrywkowej. Zakłopotanie wampira oraz jego trudności z odnalezieniem się w nowych realiach budzą śmiech, a groza wywołana niedawną masakrą robotników ustępuje miejsca komizmowi. Sceną o niewątpliwie groteskowym zabarwieniu jest rozmowa Barnabasa z Elizabeth, w której wampir wspomina swoją tragiczną miłość. Po chwili zajmuje siedzisko za elektrycznymi organami i, opierając się o klawisze, przypadkowo wzbudza instrument do gry. Z trwogą w głosie opowiada o wydarzeniach z przeszłości, akompaniując sobie kakofonią dźwięków. Nie zważa jednak na drażniące odgłosy i kontynuuje opowieść dopóty, dopóki zniecierpliwiona Elizabeth wygłusza instrument. Dramatyzm i emocjonalne napięcie wywołane przykrą historią Barnabasa zostają osłabione przez komizm, czyniąc całą sytuację absurdalną i groteskową. Równie interesująca jest rozmowa Barnabasa z nastoletnią Carolyn, w której staroświecki, ponad dwustuletni wampir słynący z burzliwych romansów, radzi się piętnastoletniej dziewczyny, jak uwieść współczesną kobietę. Największą trudność sprawia mu utrzymanie w tajemnicy swojej prawdziwej natury - zgodnie z poleceniem Elizabeth - oraz przynależności do innej epoki, które są przyczyną jego problemów towarzyskich i prowadzą do zabawnych sytuacji, w których wampir balansuje na granicy zdemaskowania ${ }^{8}$. Barnabas regularnie zdradza swoją odmienność poprzez kultywowanie osiemnastowiecznych zwyczajów, przesadną dbałość o kurtuazję i nienaganne maniery, a także archaiczną, kwiecistą mowę. Mimo to pozostali bohaterowie zdają się nie orientować, że Barnabas jest czymś więcej niż tylko ekscentrycznym indywiduum, i uczestniczą w jego grze pozorów, co zmniejsza prawdopodobieństwo prezentowanych wydarzeń i budzi śmiech widza. Groteskowość rozmowy Barnabasa z Carolyn wynika z odwrócenia ról w relacji dorosły-dziecko, w której młoda osoba jest tą bardziej doświadczoną, a dojrzały mężczyzna oczekuje od niej miłosnych porad. Źródłem groteski są różnice światopoglądowe i obyczajowe pomiędzy XVIII i XX wiekiem. Barnabas traktuje Carolyn jak dorosłą, ponieważ w jego czasach piętnastoletnie kobiety były już wydawane za mąż. Tymczasem współczesny widz, opowiadający się po stronie Carolyn, traktuje tę rozmowę jako coś moralnie niestosownego i odczuwa jej groteskowość. Przybiera ona na sile, kiedy Barnabas zaskoczony panieństwem Carolyn przestrzega ją przed uschnięciem łona na skutek seksualnej abstynencji. Groteskowa jest również nieprzystawalność wampira do współczesnych

\footnotetext{
8 Z czasem okazje się, że Carolyn również skrywa mroczną tajemnicę przed światem, ponieważ jest wilkołakiem. Zgodnie z kulturowym wizerunkiem lykantropii, może być ona wrodzona lub nabyta wskutek rzuconej klątwy. Dotknięte nią osoby posiadają cechy wilczej anatomii, takie jak zwierzęca sierść, kły czy pazury, które ujawniają się w określonych momentach, skutkując widowiskową przemianą. Połączenie cech ludzkich ze zwierzęcymi czyni lykantropię sprzeczną z prawami natury i nieprawdopodobną z racjonalnego punktu widzenia. Pozwala to zaliczyć wilkołaki do postaci groteskowych podobnie jak wampiry, gdyż są postaciami wewnętrznie sprzecznymi. Podobnie groteskowy charakter ma duch tragicznie zmarłej Josette DuPres, który ukazuje się Victorii i ostrzega ją przed zbliżającym się zagrożeniem. Obecność zjawy w świecie przedstawionym oraz możliwość kontaktowania się z nią narusza istniejący porządek i znosi - zdawałoby się nieprzekraczalną granicę pomiędzy światem żywych a światem umarłych. W filmach Burtona śmierć nie jest równoznaczna z końcem egzystencji, lecz stanowi pewien etap pośredni pomiędzy różnymi formami bytowania.
} 
realiów skutkująca serią nieporozumień i zabawnych sytuacji. Szczytem absurdu, wynikającym z rozmowy Barnabasa z Carolyn, jest pomysł socjalizacji staroświeckiego wampira w obozie hipisów, w którym ma obserwować zwyczaje i sposób myślenia młodych ludzi w XX wieku. Ambiwalentne emocje wywołuje uprzejmy komunikat wampira, który oświadcza obozowiczom, że zamierza ich wymordować, gdyż poznali zbyt wiele jego tajemnic. Uderzające jest gwałtowne przejście od łagodności do przemocy. Z ekscentrycznego przybysza z innej epoki Barnabas staje się groźnym monstrum żądnym ludzkiej krwi.

Barnabas Collins jest ośrodkiem groteskowej deformacji w filmie Mroczne cienie. Przejawia się ona na kilku poziomach. Po pierwsze, wampiryzm i klątwa nieśmiertelności rzucona na bohatera zaburzają istniejący porządek świata i są sprzeczne z prawami natury. Barnabas jest postacią groteskową, która łączy w sobie kategorialne sprzeczności, takie jak życie i śmierć. Groteskowa jest również jego dwoista osobowość. Z jednej strony posiada wszystkie atrybuty groźnego potwora - zaostrzone kły, podłużne palce zakończone szponami, nadludzką siłę i niebywały refleks. Zabijanie leży w jego naturze, podobnie jak odżywanie się ludzką krwią. Przejawem jego potworności jest również demoniczny wygląd - trupioblada twarz z podkrążonymi oczyma przywodzi na myśl niepokojące postaci z arcydzieł niemieckiego ekspresjonizmu. Z drugiej strony staroświecki wampir wyraźnie nie przystaje do współczesności, a jego rażąca odmienność i problemy adaptacyjne prowadzą nie raz do zabawnych sytuacji. Barnabas usiłuje za wszelką cenę zachować niewzruszoną minę i dostojeństwo, nawet w obliczu niepowodzeń i sytuacji ukazujących go w niekorzystnym świetle. Im bardziej chce być poważny w oczach pozostałych bohaterów, tym śmieszniejszy się wydaje widzom. W jego zachowaniu wyczuwalna jest przesada i sztuczność, a cała postać wydaje się przerysowana i karykaturalna. Barnabas budzi sprzeczne emocje - śmiech i okazjonalne przerażenie, czym wpisuje się w ramy postaci groteskowych. Towarzysząca mu groza jest jednak osłabiana przez komizm i ostatecznie sprowadzana do żartu. Mechanizm ten trafnie opisuje Jennings:

Uczucie lęku, jakie budzi koszmarny potwór, słabnie w miarę, jak zaczyna przeważać postawa rozbawienia i dystansu. Obiekt, który napawał lękiem, wydaje się teraz, mały, absurdalny, nieszkodliwy. [...] Osiągnięty zostaje stan równowagi, w którym element lęku, aczkolwiek wciąż aktualny, pojawia się w formie stłumionej jako ukryty bunt w procesie kontemplacyjnym (Jennings, 2003: 49).

Komizm Barnabasa wynika również ze sposobu, w jaki Tim Burton odnosi się do wampirycznych mitów i legend. Za przykład może posłużyć to, jak reżyser interpretuje wrażliwość wampirów na światło. Barnabas unika światła słonecznego, ponieważ przy dłuższym z nim kontakcie mógłby spłonąć żywcem. Paradoksalnie w innych scenach wampirowi wystarcza ciemny parasol, kapelusz i okulary przeciwsłoneczne, by poruszać się w świetle dziennym bez obawy o własne zdrowie? . Równie żartobliwie

\footnotetext{
9 Motyw wampira przechadzającego się w świetle dziennym może być nawiązaniem do filmu Dracula (1992) Francisa Forda Coppoli, w którym przyjęło się, że wampiry mogą poruszać się za dnia, ale są w tym czasie bardzo osłabione i mniej groźne.
} 
zostało zinterpretowane upodobanie wampirów do trumien. Zanim Barnabas zorganizował sobie własną trumnę, zmuszony był wypoczywać w przypadkowych miejscach, które nie pozwalały mu się w pełni zregenerować. Sypiał między innymi w kartonowym pudle, we wnętrzach szaf, na zasłonach okiennych oraz pod baldachimem rozciągniętym nad wielkim łożem. Burton parodiuje również mity o hipnotycznych mocach wampirów. Barnabas wykorzystuje je na pijanym Williem, którego chce przysposobić sobie na osobistego sługę. Z początku wampir odnosi porażkę, gdyż Willie traci świadomość i zasypia w trakcie rozmowy ${ }^{10}$. Udaje mu się dopiero za drugim razem, co świadczy o tym, że panowanie nad cudzymi myślami nie jest łatwą sztuką i sprawia trudności nawet wiekowym wampirom. Najbardziej groteskowym przepracowaniem wampirycznych mitów jest koncepcja transfuzji krwi, dzięki której Barnabas ma odzyskać utraconą śmiertelność i wyleczyć się z wampiryzmu. Nie zdaje sobie jednak sprawy z tego, że przemiana w wampira jest nieodwracalna i nie cofną jej nawet najbardziej wymyślne zabiegi. Poza Barnabasem znamiona groteskowości mają również bohaterowie drugoplanowi. Przykładem jest doktor Hoffman, pani psychiatra opiekująca się młodym Davidem niesłusznie podejrzewanym o problemy psychiczne. Jej ekscentryzm i osobliwe zwyczaje stoją w sprzeczności z etyką lekarską. Kobieta jest uzależniona od alkoholu i jak określa to jedna z bohaterek, regularnie przeżywa „jeden ze swoich legendarnych kaców”. Hoffman wspomaga się również środkami psychotropowymi, a z jej zachowania można wnioskować, że potrzebuje fachowej pomocy bardziej niż David. Jej uzależnienia i lekceważący stosunek do obowiązków przeczą powszechnym wyobrażeniom na temat psychiatrów, którzy powinni troszczyć się o pacjentów, wzbudzać zaufanie oraz poczucie bezpieczeństwa. Doktor Hoffman bardziej jednak interesuje uwodzenie Barnabasa i pokusa wiecznej młodości spowodowanej wampiryzmem aniżeli lojalność wobec rodziny Collinsów czy pomoc Davidowi. Jest ona postacią jednocześnie śmieszną i budzącą trwogę. Śmiechowi wywołanemu jej osobliwym zachowaniem towarzyszy jednak gorzka refleksja związana z domniemanym kontekstem intertekstualnym bohaterki. Można bowiem przypuszczać, że reżyser zmagający się w młodości z problemami psychicznymi wykreował fikcyjną postać w oparciu o rzeczywistą osobę. Nie wiadomo, jak wiele z cech parodiowanych i wyolbrzymianych u doktor Hoffman jest inspirowana rzeczywistością pozatekstową oraz osobistymi doświadczeniami Tima Burtona. Groteskowy charakter mają również postaci służących Collinsów - podstarzały kawaler Willie oraz milcząca pani Johnson, którzy w niczym nie przypominają ponurej służby z klasycznych filmów grozy. Willie jest prostolinijnym mężczyzną, który nie zadaje sobie trudu, by godnie reprezentować swoich pracodawców. Lekceważy swoje obowiązki i nie troszczy się o zabytkowe wnętrza Collinwood, w których widzi jedynie stertę wietrzejących cegieł i zbieraninę kurzu. Willie jest zaniedbany z wyglądu i nie stroni alkoholu.

\footnotetext{
${ }^{10}$ Barnabas jeszcze raz próbuje swoich hipnotycznych mocy, tym razem z powodzeniem, podczas rozmowy z kapitanem Clarneyem, w którego roli wystąpił gościnnie Christopher Lee. Brytyjski aktor był wielokrotnym odtwórcą roli hrabiego Draculi. Występował także w większości horrorów wyprodukowanych przez wytwórnię Hammer, których fanem od najmłodszych lat jest Tim Burton (zob. Has-Tokarz, 2011: 237; Zabłocka-Skorek, 2010: 340).
} 
Potrafi skomentować coś w mało wybredny sposób i z rozbrajającą szczerością. Natomiast komizm pani Johnson wynika przede wszystkim z jej nieprzeniknionej osobowości. Milcząca staruszka wydaje się oderwana od rzeczywistości i nie reaguje na to, co mówią do niej pozostali bohaterowie. Pojawia się w niespodziewanych miejscach i zaskakuje swoim osobliwym zachowaniem. Podczas koncertu rockowego w rezydencji Collinsów, który sam w sobie kontrastuje z ponurą aurą Collinwood i przełamuje konwencję strasznego dworu, staruszka siedzi w pobliżu olbrzymiego głośnika i spokojnie czyta książkę. Zdaje się nie zważać na hałas (jest prawdopodobnie niesłysząca) i relaksuje się dzięki wciągającej lekturze. Postaci służących są jedną z części składowych filmowego komizmu i uczestniczą w zabawnych, nierzadko absurdalnych sytuacjach.

Powyższe rozważania dowodzą, jak wiele elementów świata przedstawionego zostało poddane groteskowym przekształceniom. Estetyka groteski widoczna jest niemal w każdym aspekcie Mrocznych cieni, od scenografii inspirowanej niemieckim ekspresjonizmem i horrorem gotyckim, przez nieszablonowe kreacje bohaterów, zaskakujące dialogi i sytuacje, po twórcze wykorzystanie chwytów dramaturgii filmowej wbrew powszechnym oczekiwaniom odbiorców. W rezultacie widzowie nigdy nie mogą być pewni tego, co zobaczą w następnej scenie. Specyficzna technika realizacji dzieł Burtona stymuluje rozwój gatunków filmowych, a w szczególności horroru, który wywiera istotny wpływ na twórczość reżysera. Proces ewolucji horroru obrazują rozważania Iwony Kolasińskiej:

Horror stale ewoluuje, przy zachowaniu względnie stałych wyznaczników gatunkowości; zmienia się przez anektowanie innych gatunków, poszukiwanie nowych realizacji modelu, grę z konwencjami lub ich negocjację a nawet przedefiniowanie tychże wyznaczników (Kolasińska, 1998: 120).

Słowa Kolasińskiej trafnie oddają strategię stosowaną przez Tima Burtona. Jego rozpoznawalny styl opiera się na łączeniu różnorodnych schematów przedstawieniowych i konwencji gatunkowych, które poddawane są rozmaitym przekształceniom. W rezultacie takich połączeń, wzbogaconych dużą ilością intertekstualnych odniesień, powstaje oryginalny język filmowy cieszący się uznaniem widzów na całym świecie, czego dowodzą wysokie wyniki oglądalności filmów Burtona (Żakieta, 2013: 267). Jego twórczość zaskakuje oryginalnymi rozwiązaniami, podobnie jak zaskakiwał widzów George Méliès eksperymentujący z medium filmowym na początku $X X$ wieku, i ustanawia nową jakość we współczesnym kinie popularnym.

\section{Bibliografia}

Buryła S. (2006), Nobilitacja groteski, „Teksty Drugie”, nr 4.

Carroll N. (2004), Filozofia horroru albo paradoksy uczuć, przeł. M. Przylipiak, Słowo/obraz terytoria, Gdańsk. 
Głowiński M. (1986), O intertekstualności, „Pamiętnik Literacki”, nr 4.

Głowiński M. (2000), Groteska we wspótczesnej literaturze polskiej, [w:] R. Nycz (red.), Intertekstualność, groteska, parabola. Szkice ogólne i interpretacje, Universitas, Kraków.

Głowiński M. (2003), Groteska jako kategoria estetyczna, [w:] M. Głowiński (red.), Groteska, Słowo/obraz terytoria, Gdańsk.

Has-Tokarz A. (2011), Horror w literaturze wspótczesnej i filmie, UMCS, Lublin.

Janus-Sitarz A. (1997), Groteska literacka. Od diabła w Damaszku po Becketta i Mrożka, Universitas, Kraków.

Jennings L.B. (2003), Termin "groteska", przeł. M.B. Fedewicz, [w:] M. Głowiński (red.), Groteska, Słowo/obraz terytoria, Gdańsk.

Kayser W. (2003), Próba określenia istoty groteskowości, przeł. R. Handke, [w:] M. Głowiński (red.), Groteska, Słowo/obraz terytoria, Gdańsk.

Kolasińska I. (1998), Kiedy spojrzenie Gorgony budzi upiory: horror filmowy i jego widz, [w:] K. Loska (red.), Kino gatunków. Wczoraj i dziś, Rabid, Kraków.

McElroy B. (2003), Groteska i jej wspótczesna odmiana, przeł. M.B. Fedewicz, [w:] M. Głowiński (red.), Groteska, Słowo/obraz terytoria, Gdańsk.

Onimus J. (2003), Groteskowość a doświadczenie świadomości, przeł. K. Falicka, [w:] M. Głowiński (red.), Groteska, Słowo/obraz terytoria, Gdańsk.

Sokół L. (1970), Przegląd prac o grotesce w literaturze, „Pamiętnik Literacki”, z. 4.

Stańczuk M. (2015), Tropologiczna koncepcja groteski, „Przegląd Filozoficzno-Literacki”, nr 1(41).

Starnawski B. (2008), Groteskowe "światy możliwe”, "Tekstualia”, nr 2(13).

Stolarek J. (2014), Groteska w wybranych utworach pisarzy okresu miedzywojennego, „Conversatoria Linguistica", R. VIII.

Weishaar S.R. (2012), Masters of the Grotesque. The Cinema of Tim Burton, Terry Gilliam, the Coen Brothers and David Lynch, McFarland \& Company, Inc., Jefferson, North Carolina, and London.

Zabłocka-Skorek J. (2010), Tim Burton - dziwak w Fabryce Snów, [w:] Ł. Plesnar, K. Loska (red.), Mistrzowie kina amerykańskiego. Współczesność, Rabid, Kraków.

Żakieta K. (2013), Autorskie (od)tworzenie. O intertekstualnych wątkach w twórczości Tima Burtona, „Ogrody Nauk i Sztuk”, nr 3. 